Public Inspiration: Jurnal Administrasi Publik
https:/ejournal.warmadewa.ac.id/index.php/public-inspiration

\title{
Evaluasi Kebijakan Sistem Zonasi dalam Penerimaan Peserta Didik Baru (PPDB) di Sekolah Menengah Pertama Negeri (SMPN) i Abiansemal
}

\author{
I Kadek Dede Junaedy*, I Made Mardika, dan I Made Yudhiantara \\ Program Magister Administrasi Publik, Program Pascasarjana, Universitas Warmadewa \\ Email-corespondence: dedejunaedy55@gmail.com
}

How to Cite: Junaedy, I, K, D., Mardika, I, M., Yudhiantara, I, M. (2021). Evaluasi Kebijakan Sistem Zonasi dalam Penerimaan Peserta Didik Baru (PPDB) di Sekolah Menengah Pertama Negeri (SMPN) 1 Abiansemal. Public Inspiration: Jurnal Administrasi Publik, 6 (2): 107-115. DOI: https://doi.org/10.22225/pi.6.2.2021.107 $-115$

\begin{abstract}
Evaluation of the Zoning System Policy in the Admission of New Students (PPDB) at State Junior High School (SMPN) 1 AbiansemalThe zoning system policy in its implementation at SMPN 1 Abiansemal has problems, web is difficult to open during the school selection process by students and since the implementation of the school zoning system it has been difficult to find students who have different academic achievements from when admitting students through the TPA route. This shows that it is necessary to evaluate the zoning system policy. The purpose of this study was to evaluate the zoning system policy in the Admission of New Students at SMPN 1 Abiansemal in terms of equal access and quality of education, as well as to find supporting factors and obstacles to the implementation of zoning system policies at SMPN 1 Abiansemal.The research method used is qualitative research methods. The results showed that the zoning system policy was not implemented effectively and efficiently. And it has not been able to create equal access and equal quality in the Admission of New Students at SMPN 1 Abiansemal, because the zoning has not been carried out evenly and there has been a decline in the quality of schools. Supporting factors of the implementation of the zoning system policy in the Admission of New Students at SMPN 1 Abiansemal, including coordination of the office and the school principal, and having SOPS and technical guidelines for implementing zoning system policies in new student admissions at SMPN 1 Abiansemal. The inhibiting factors for the implementation of the Zoning system policy at SMPN 1 Abiansemal include lack of facilities and infrastructure, lack of human resources, limiting the number of quotas and zoning based on the address of the banjar, and pressure from school external parties.
\end{abstract}

Keywords: evaluation; zoning system

\begin{abstract}
Abstrak
Evaluasi Kebijakan Sistem Zonasi Dalam Penerimaan Siswa Baru (PPDB) di Sekolah Menengah Pertama Negeri (SMPN) 1 AbiansemalKebijakan sistem zonasi dalam penerapannya di SMPN 1 Abiansemal bermasalah, web sulit dibuka saat proses seleksi sekolah oleh siswa dan sejak diterapkannya sistem zonasi sekolah sulit menemukan siswa yang memiliki prestasi akademik berbeda dari saat penerimaan siswa melalui jalur TPA. Hal ini menunjukkan bahwa perlu dilakukan evaluasi terhadap kebijakan sistem zonasi. Tujuan penelitian ini adalah untuk mengevaluasi kebijakan sistem zonasi pada Penerimaan Siswa Baru di SMPN 1 Abiansemal ditinjau dari pemerataan akses dan mutu pendidikan, serta untuk mengetahui faktor pendukung dan penghambat penerapan kebijakan sistem zonasi di SMPN 1 Abiansemal.Metode penelitian yang digunakan adalah metode penelitian kualitatif. Hasil penelitian menunjukkan bahwa kebijakan sistem zonasi belum dilaksanakan secara efektif dan efisien. Dan itu belum mampu menciptakan pemerataan akses dan pemerataan kualitas dalam Penerimaan Siswa Baru di SMPN 1 Abiansemal, karena zonasi belum dilakukan secara merata dan telah terjadi penurunan kualitas sekolah. Faktor pendukung penerapan kebijakan sistem zonasi dalam Penerimaan Siswa Baru di SMPN 1 Abiansemal, antara lain koordinasi kantor dan kepala sekolah, serta memiliki SOP dan petunjuk teknis pelaksanaan kebijakan sistem zonasi dalam penerimaan siswa baru di SMPN 1 Abiansemal. Adapun faktor penghambat penerapan kebijakan sistem zonasi di SMPN 1 Abiansemal antara lain kurangnya sarana dan prasarana, kurangnya sumber daya manusia, pembatasan jumlah kuota dan zonasi berdasarkan alamat banjar, dan tekanan dari pihak eksternal sekolah.
\end{abstract}

Kata kunci: evaluasi; sistem zonasi 


\section{Pendahuluan}

Kesenjangan kualitas pendidikan menjadi permasalahan pembangunan pendidikan,untuk dapat mengatasi permasalahan kesenjangan ini Pemerintah Indonesia mengeluarkan kebijakan sistem zonasi didalam proses Penerimaan Peserta Didik Baru (PPDB). Mengacu pada Peraturan Menteri Pendidikan dan Kebudayaan Republik Indonesia Nomor 44 Tahun 2019 Tentang Penerimaan Peserta Didik Baru Pada Taman Kanak-Kanak, Sekolah Dasar,Sekolah Menengah Pertama, Sekolah Menengah Atas dan Sekolah Menengah Kejuruan.

Sistem Zonasi bertujuan untuk (1) menjamin penerimaan peserta didik baru berjalan secara obyektif, transparan, akuntabel, nondiskriminatif, dan berkeadilan dalam rangka mendorong peningkatan akses layanan pendidikan; (2) menjamin ketersediaan dan kesiapan satuan pendidikan (Sekolah Negeri Khususnya) untuk dapat memberikan layanan pendidikan yang berkualitas; (3) menjamin adanya pemerataan akses dan mutu pendidikan yang berkeadilan pada setiap zona/wilayah yang ditetapkan mendekati tempat tinggal peserta didik; (4) memastikan terpenuhinya tenaga pendidik dan kependidikan yang kompeten didukung oleh prasarana dan sarana yang memadai, serta dapat disediakan dan digunakan bersama oleh setiap satuan pendidikan di wilayah/zona yang telah ditetapkan; (5) mengendalikan dan menjamin mutu lulusan serta melakukan pengawasan proses dan hasil pembelajaran secara komparatif dan kompetitif pada wilayah/zona layanan pendidikan secara terukur dan berkesinambungan (Setjen Kemendikbud, 2018: 4). Namun terjadi beberapa permasalahan terhadap penerapan sistem zonasi yaitu:

"Permasalahan pertama, teknis pelaksanaan PPDB menimbulkan kericuhan di kalangan masyarakat. Permasalahan kedua adalah ketersediaan sekolah negeri belum merata di semua daerah, sementara aturan zonasi mewajibkan anak mendaftar ke sekolah terdekat dengan rumahnya. Permasalahan ketiga, sistem zonasi dengan prioritas jarak menyebabkan motivasi belajar peserta didik menurun, karena nilai atau prestasi menjadi dianggap tidak penting. Permasalahan keempat, dikotomi sekolah unggulan dan nonunggulan masih berkembang di masyarakat. Permasalahan kelima, koordinasi antar instansi terkait belum efektif sehingga kebijakan pendidikan yang berlaku tidak berkesinambungan". (Dinar, 2019:14)

Permasalahan di atas merupakan permasalahan pelaksanaan kebijakan yang dialami oleh beberapa sekolah di Indonesia baik dari jenjang pendidikan tingkat Taman KanakKanak (TK), Sekolah Dasar (SD), Sekolah Menengah Pertama (SMP) dan Sekolah Menengah Atas (SMA) khususnya sekolah negeri. Setiap daerah di Indonesia melaksanakan kebijakan sistem zonasi dalam Penerimaan Peserta Didik Baru. Bali merupakan salah satu daerah di Indonesia yang melaksanakan kebijakan sistem zonasi dalam Penerimaan Peserta Didik Baru (PPDB), pada tahun 2019 Bali masuk kedalam 10 besar wilayah yang banyak mengadukan masalah dalam pelaksanaan sistem zonasi, pengaduan yang disampaikan mengenai masalah sosialisasi yang minim, petunjuk teknis yang tidak jelas, pembagian zonasi yang dianggap tidak adil dan sekolah negeri yang tidak merata penyebarannya (balicitizen.com, 2020). Untuk dapat melaksanakan tujuan sistem zonasi, yaitu pemerataan kualitas pendidikan masih menjadi permasalahan di Bali khususnya di tingkat Sekolah Menengah Pertama, dimana berdasarkan pada data Podes 2018 mencatat terdapat 311 Sekolah SMP yang masih aktif di Bali serta dari total 716 total desa/kelurahan yang ada di Bali sebanyak $405(56,5 \%)$ desa atau kelurahan yang belum memiliki sarana pendidikan di tingkat SMP (Balipost,2019).

Kabupaten Badung merupakan salah satu Kabupaten yang ada di Bali yang telah melaksanakan kebijakan sistem zonasi dengan dikeluarkannya Peraturan Bupati Badung Nomor 17 Tahun 2020 Tentang Penerimaan Peserta Didik Baru Tingkat Taman KanakKanak, Sekolah Dasar dan Sekolah Menengah Pertama,. Termasuk Kabupaten yang mengalami permasalahan utama, yaitu kesenjangan jumlah Sekolah Dasar Negeri (SDN) dengan 
jumlah Sekolah Menengah Pertama Negeri (SMPN) yang terdapat di beberapa kecamatan, hal ini akan mempersulit untuk menciptakan pemerataan pendidikan sesuai dengan tujuan kebijakan sistem zonasi, jumlah sekolah ditunjukkan pada tabel 1di bawah ini:

\section{Tabel 1. Jumlah SD dan SMP Negeri Berdasarkan Kecamatan Kabupaten Badung Ta- hun 2019}

\begin{tabular}{cccc}
\hline NO. & Kecamatan & SD & SMP \\
\hline 1. & Kuta Selatan & 40 & 5 \\
2. & Kuta & 19 & 3 \\
3. & Kuta Utara & 25 & 4 \\
4. & Mengwi & 71 & 7 \\
5. & Abiansemal & 64 & 5 \\
6. & Petang & 27 & 4 \\
& Jumlah & 264 & 28 \\
\hline
\end{tabular}

Sumber:https://referensi.data.kemdikbud.go.id/, 2020

Tabel 1 menunjukkan bahwa terdapat 6 kecamatan di Kabupaten Badung dan semua kecamatan mengalami permasalahan kesenjangan jumlah SDN dengan jumlah SMPN di mana total keseluruhan jumlah Sekolah Dasar Negeri (SDN) sebanyak 264 sekolah sedangkan jumlah Sekolah Menengah Pertama Negeri (SMPN) sebanyak 28 sekolah. Salah satu kecamatan yang mengalami permasalahan ini yaitu Kecamatan Abiansemal, jumlah SDN di Kecamatan Abiansemal sebanyak 64 sekolah sedangkan SMPN sebanyak 5 sekolah. Dari 5 SMP Negeri yang ada di Kecamatan Abiansemal terdapat SMP Negeri unggulan, yaitu SMPN 1 Abiansemal. SMPN 1 Abiansemal menjadi sekolah unggulan karena prestasi yang dimiliki oleh Sekolah ini baik prestasi akademik maupun non akademik, serta merupakan sekolah yang terakreditasi A. Setelah penerapan kebijakan zonasi sekolah unggulan telah dihapuskan.

Dalam pelaksanaan kebijakan sistem zonasi di SMPN 1 Abiansemal terdapat permasalahan, yaitu web PPDB sulit dibuka saat proses pemilihan sekolah oleh siswa. Semenjak pelaksanaan sistem zonasi sekolah mengalami kesulitan untuk mendapatkan anak yang memiliki prestasi akademik berbeda dengan saat penerimaan siswa melalui jalur TPA. Saat ini di SMPN 1 Abiansemal terdapat beberapa anak yang tidak bisa membaca. Permasalahan lainnya yang dihadapi oleh SMP N 1 Abiansemal dalam pelaksanaan Penerimaan Peserta Didik Baru (PPDB) dengan sistem zonasi, yaitu masalah koordinasi dengan pihak Dinas Pendidikan Kabupaten Badung mengenai siswa yang diterima di SMPN 1 Abiansemal, seperti yang disampaikan oleh Waka Kurikulum bahwa :

"setiap tahun pelaksanaan sistem zonasi terdapat anak titipan yang sebenarnya zonasinya tidak masuk di sekolah ini, tetapi pihak sekolah tetap harus menerima karena mereka membawa memo dari pihak dinas. Pihak Sekolah tidak bisa menolak sesuai dengan aturan sehingga terjadi pembekakan jumlah siswa yang diterima di sekolah ini. Dimana yang seharusnya mereka bersekolah di SMPN 5 Abiansemal, maka terjadi kesenjangan jumlah siswa antara SMPN 5 Abiansemal dengan SMPN 1 Abiansemal, SMPN 5 kekurangan siswa dan SMPN 1 kelebihan siswa. Kami dari pihak sekolah merasa mendapatkan tekanan dari pihak dinas, sebenarnya disini kami hanya ingin membuka 7 kelas tetapi dari pihak dinas protes dan meminta untuk membuka kelas menjadi 8 kelas. Hal ini terjadi karena SMPN 1 Abiansemal tetap dianggap menjadi sekolah unggulan oleh masyarakat sehingga masyarakat tetap menuntut untuk bersekolah di SMPN 1 Abiansemal terutama yang berada di luar zona"

Sesuai dengan permasalahan-permasalahan yang terjadi dilapangan dalam pelaksa- 
naan kebijakan sistem zonasi di SMPN 1 Abiansemal, maka perlu untuk melakukan evaluasi terhadap kebijakan sistem zonasi. Evaluasi kebijakan adalah kegiatan yang menyangkut estimasi atau penilaian kebijakan yang mencakup substansi, implementasi dan dampak (Anderson,1975:168). Pada penelitian ini evaluasi yang akan dilakukan yaitu pada upaya pemerataan akses dan mutu pendidikan ditinjau dari kriteria evaluasi menurut William $\mathrm{N}$. Dunn (1999:610) terdiri dari efektivitas, efisiensi, kecukupan, perataan, responsivitas dan ketepatan. Sehingga berdasarkan pemaparan permasalahan diatas penulis tertarik untuk melakukan penelitian dengan judul "Evaluasi Kebijakan Sistem Zonasi dalam Penerimaan Peserta Didik Baru (PPDB) di Sekolah Menengah Pertama (SMP) Negeri 1 Abiansemal”.

\section{Konsep}

\section{Evaluasi Kebijakan Publik}

Menurut Lester dan Stewart (Winarno, 2008:166) evaluasi kebijakan dapat dibedakan kedalam dua tugas berbeda, tugas pertama adalah untuk menentukan konsekuensikonsekuensi yang ditimbulkan oleh suatu kebijakan dengan cara menggambarkan dampaknya. Sedangkan tugas kedua adalah untuk menilai keberhasilan atau kegagalan dari suatu kebijakan berdasarkan standar atau kriteria yang ditetapkan sebelumnya.

\section{Sistem Zonasi}

Sistem zonasi yang mengatur mengenai zona wilayah bagi calon siswa dimuat dalam Sistem PPDB (Penerimaan Peserta Didik Baru) yang baru melalui Permendikbud No.44 Tahun 2019. Sistem zonasi terbaru ini prinsipnya hampir sama dengan sistem bina lingkungan, hanya saja pada jumlah kuota sistem zonasi ini jauh lebih banyak dibandingkan bina lingkungan yaitu mencapai 90\%.

\section{Mutu Pendidikan}

Mutu Pendidikan menurut Permendiknas Nomor 63 Tahun 2009 adalah tingkat kecerdasan kehidupan bangsa yang dapat diraih dari penerapan Sistem Pendidikan Nasional. Berdasarkan pada beberapa definisi mutu pendidikan, jadi mutu pendidikan adalah pengembangan sumber daya manusia melalui sistem pendidikan.

\section{Pemerataan Akses}

Pengertian pemerataan di dalam dunia pendidikan, yaitu menurut Tilaar (1993:31) secara konsepsional tedapat dua konsep pemerataan, yaitu pemerataan aktif dan pemerataan pasif. Pemerataan pasif adalah pemerataan yang lebih menekankan pada kesamaan memperoleh kesempatan untuk mendaftar di sekolah, sedangkan pemerataan aktif bermakna kesamaan dalam memberi kesempatan kepada murid-murid terdaftar agar memperoleh hasil belajar setinggi-tingginya.

\section{Evaluasi Kebijakan Publik}

Evaluasi adalah menilai manfaat dari proses serta program pemerintah (Jones,1996:365). Selanjutnya, secara umum evaluasi kebijakan dapat dikatakan sebagai kegiatan yang menyangkut estimasi atau penilaian kebijakan mencakup substansi, implementasi dan dampak pelaksanaan kebijakan tersebut (Winarno,2008:166). Teori yang digunakan pada penelitian ini, yaitu kriteria evaluasi kebijakan menurut William N.Dunn, dimana dalam evaluasi suatu program atau kebijakan publik diperlukan adanya suatu kriteria. Kriteria evaluasi kebijakan yang dikembangkan oleh William N. Dunn $(1999 ; 610)$ terdiri dari beberapa indikator yaitu:

\section{Efektivitas (effectiveness).}

Berkenaan dengan suatu alternatif mencapai hasil (akibat) yang diharapkan, atau mencapai tujuan dari diadakannya tindakan. Efektivitas, yang secara dekat berhubungan dengan rasionalitas teknis, selalu diukur dari unit produk atau layanan serta nilai moneter. 


\section{Efisiensi (efficiency).}

Berkenaan dengan jumlah usaha yang diperlukan untuk menghasilkan tingkat efektivitas tertentu. Efisiensi biasanya ditentukan melalui perhitungan biaya per unit produk atau layanan. Kebijakan yang mencapai efektivitas tertinggi dengan biaya terkecil dinamakan efisien.

\section{Kecukupan (adequacy).}

Kecukupan dalam kebijakan publik dapat dikatakan tujuan yang telah dicapai sudah dirasakan mencukupi dalam berbagai hal. Kecukupan berkenaan dengan seberapa jauh suatu tingkat efektivitas serta alternatif kebijakan dapat memuaskan kebutuhan, nilai dan menyelesaikan masalah yang terjadi.

Pemerataan (Equity).

Pemerataan dalam kebijakan publik dapat dikatakan mempunyai arti dengan keadilan yang diberikan dan diperoleh sasaran kebijakan publik. Kriteria pemerataan (equity) erat hubungannya dengan rasionalitas legal dan sosial. Serta kesesuaian pada distribusi akibat dan usaha antara kelompok-kelompok yang berbeda dalam masyarakat. Kebijakan yang berorientasi pada perataan adalah kebijakan yang akibat dan usaha secara adil didistribusikan.

\section{Responsivitas (Responsiveness).}

Responsivitas dalam kebijakan publik dapat diartikan sebagai respon dari suatu aktivitas, berarti tanggapan sasaran kebijakan publik atas penerapan suatu kebijakan. Responsivitas berkenaan dengan seberapa jauh kebijakan dapat memuaskan kebutuhan, preferensi, atau nilai kelompok-kelompok masyarakat tertentu. Keberhasilan kebijakan dapat dilihat melalui tanggapan masyarakat dalam bentuk dukungan atau berupa penolakan untuk menanggapi pelaksanaan kebijakan, setelah dampak kebijakan sudah mulai dapat dirasakan. Kriteria responsivitas penting karena analisis yang dapat memuaskan semua kriteria lainnya (efektivitas, efisiensi, kecukupan, kesamaan), kebijakan dianggap masih gagal jika belum menanggapi kebutuhan aktual dari kelompok yang semestinya diuntungkan dari adanya kebijakan. Oleh karena itu, kriteria responsivitas cerminan nyata kebutuhan, preferensi, dan nilai dari kelompok tertentu terhadap kriteria efektivitas, efisiensi, kecukupan dan kesamaan.

\section{Ketepatan (Appropriateness).}

Ketetapan merujuk pada nilai atau harga dari tujuan program dan pada kuatnya asumsi yang melandasi tujuan-tujuan tersebut. Kriteria yang dipakai untuk menseleksi sejumlah alternatif untuk dijadikan rekomendasi dengan menilai hasil dari alternatif tersebut merupakan pilihan tujuan yang layak. Kriteria kelayakan dihubungkan dengan substansi tujuan, bukan cara atau instrumen untuk merealisasikan tujuan tersebut.

\section{Metode}

Metode yang digunakan dalam penelitian ini adalah metode penelitian kualitatif dengan pendekatan deskriptif, dimana metode penelitian deskriptif adalah penelitian yang berusaha mendeskripsikan suatu gejala, peristiwa, kejadian yang terjadi saat ini. Penelitian deskriptif memusatkan pada permasalahan aktual sebagaimana adanya pada saat penelitian berlangsung. Sedangakan metode penelitian kualitatif digunakan untuk menganalisis dan medeskripsikan fenomena yang terjadi pada objek penelitian, yaitu evaluasi kebijakan sistem zonasi di SMPN 1 Abiansemal.

Instrumen penelitian pada penelitian ini adalah penulis berperan sebagai instrumen utama dalam menjaring data dan informasi yang diperlukan. Untuk mengumpulkan informasi maka diperlukan instrumen pendukung lainnya, yaitu wawancara dengan menggunakan pedoman wawancara. Wawancara merupakan alat yang andal untuk mengungkapkan ken- 
yataan hidup serta yang dipikirkan atau dirasakan orang tentang berbagai aspek kehidupan melalui tanya jawab menurut Nasution (200:114). Jenis wawancara yang peneliti gunakan pada penelitian ini adalah wawancara tak terstruktur.

\section{Hasil Penelitian dan Pembahasan}

\section{Evaluasi Kebijakan Sistem Zonasi Dalam Penerimaan Peserta Didik Baru (PPDB) di SMPN 1 Abiansemal}

Evaluasi kebijakan sistem zonasi yang ditinjau dari kriteria evaluasi menurut William N. Dunn, yaitu terdiri dari efektivitas, efisiensi, kecukupan, pemerataan, responsivitas dan ketepatan. Pelaksanaan kebijakan sistem zonasi di SMPN 1 Abiansemal belum dilaksanakan secara efektif dan efisien. Selain itu pemerataan akses dan pemerataan mutu dalam pelaksanaan kebijakan sistem zonasi di SMPN 1 Abiansemal belum tercapai. Pemerataan akses dalam dunia pendidikan menurut Tilaar (1993:31) secara konsepsional terdiri dari dua konsep pemerataan, pemerataan pasif dan pemerataan aktif. Pemerataan pasif adalah pemerataan yang lebih menekankan pada kesamaan memperoleh kesempatan untuk mendaftar di sekolah, sedangkan pemerataan aktif bermakna kesamaan dalam membecari kesempatan kepada murid-murid terdaftar agar memperoleh hasil belajar setinggi-tingginya.

Sesuai dengan definisi dari pemerataan akses tersebut, maka pelaksanaan kebijakan sistem zonasi di SMPN 1 Abiansemal belum dilaksanakan dengan baik, hal ini karena pemerataan secara pasif belum berjalan dengan baik meskipun telah memberikan kesamaan dalam memperoleh kesempatan untuk mendaftar sekolah tetapi kuota yang ditetapkan tidak terpenuhi, terjadi kesenjangan, dan penerimaan siswa tidak sesuai dengan zona yang telah ditentukan. Selain itu sesuai dengan definisi dari pemerataan aktif, yaitu memberikan kesempatan kepada murid-murid terdaftar agar memperoleh hasil belajar setinggi-tingginya namun kenyataan yang terjadi setelah kebijakan ini dilaksanakan terjadinya penurunan hasil belajar siswa sehigga prestasi sekolah SMPN 1 Abiansemal menggalami penurunan.

Pemerataan mutu pendidikan belum dilaksanakan dengan baik di SMPN 1 Abiansemal. Karena terjadinya penurunan mutu pendidikan, menurut Permendikbud Nomor 63 Tahun 2009 mutu pendidikan adalah tingkat kecerdasan kehidupan bangsa yang dapat diraih dari penerapan Sistem Pendidikan Nasional, yaitu sistem zonasi yang seharusnya dengan adanya sistem ini dapat meningkatkan kecerdasan tetapi yang terjadinya penurunan kecerdasan dengan dibuktikannya pihak sekolah SMPN 1 Abiansemal sampai saat ini menggalami kesulitan dalam mencari siswa beprestasi. Serta dari respon yang diberikan oleh guru, orang tua siswa dan siswa SMPN 1 Abiansemal menginginkan agar sistem zonasi di hapuskan dan kembali seperti dulu menggunakan tes dan NEM. Kecukupan dan ketepatan kebijakan sistem zonasi dalam pelaksanaan di SMPN 1 Abiansemal belum tercapai terutama ketepatan dalam penentuan zona.

Permasalahan utama yang ditemukan di lapangan yang menyebabkan belum tercapainya tujuan pemerataan akses dan pemerataan mutu pendidikan dalam pelaksanaan kebijakan sistem zonasi di SMPN 1 Abiansemal, yaitu karena ketidak jelasan aturan untuk penetapan zona yang hanya berdasarkan alamat Banjar dan tidak dijelaskan lagi radius atau jarak banjar yang bisa masuk ke dalam zona SMPN 1 Abiansemal serta ke tegasan dalam penetapan jalur penerimaan peserta didik baru, karena terdapat jalur penerimaan yang tidak sesuai dengan aturan serta menerima peserta didik di luar zona yang ditentukan. Jadi, tidak berhasilnya pelaksanaan kebijakan sistem zonasi sangat ditentukan dengan letak geografis, ketersediaan infrastruktur lembaga pendidikan terutama sekolah negeri yang belum merata di setiap kecamatan/desa, ketegasan seorang pemimpin dalam menegakan aturan, dan komunikasi mengenai kebijakan serta wewenang antara lembaga pemerintahan, dalam hal ini pihak Sekolah SMPN 1 Abiansemal dengan Dinas Pendidikan, Pemuda dan Olaharaga Kabupaten Badung.

\section{Faktor Pendukung dan Penghambat}


Adapun faktor pendukung dari pelaksanaan kebijakan sistem zonasi di SMPN 1 Abiansemal yaitu informasi tentang PPDB mudah di akses, adanya pelatihan yang diberikan oleh pihak dinas kepada tim PPDB di SMPN 1 Abiansemal, adanya koordinasi pihak dinas dan Kepala Sekolah sebelum serta setelah PPDB di laksanakan di SMPN 1 Abiansemal, serta telah memiliki SOP dan Juknis pelaksanaan kebijakan sistem zonasi dalam PPDB (Penerimaan Peserta Didik Baru) di SMPN 1 Abiansemal.

Sedangkan faktor-faktor penghambat dari pelaksanaan kebijakan sistem zonasi di SMPN 1 Abiansemal, yaitu kurangnya sarana dan prasarana, masih minimnya SDM (Sumber Daya Manusia). Dimana yang menjadi operator PPDB dari pihak guru sedangkan seharusnya sesuai aturan pihak TU yang memiliki wewenang untuk menjadi operator, tetapi disini ada 4 guru yang menjadi operator dan hanya satu guru yang memiliki SK sebagai operator sisanya membantu saat verifikasi dan penerimaan sehingga guru-guru ini tidak mendapatkan tunjangan kerja sebagai operator karena tidak sesuai dengan aturan.

Pembatasan jumlah kuota yang ditentukan dari pihak sekolah tidak sebanding dengan jumlah calon peserta didik yang masuk didalam zona SMPN 1 Abiansemal, penetapan zona berdasarkan alamat banjar dan jarak menjadi penghambat untuk menciptakan pemerataan akses pendidikan, tekanan dari pihak eksternal sekolah, kurang tegasnya pemimpin dalam menegakkan aturan, kurangnya komunikasi mengenai aturan yang mengatur pelaksanaan kebijakan sistem zonasi di Kabupaten Badung antara pihak Dinas Pendidikan, Pemuda dan Olahraga dengan pihak sekolah SMPN 1 Abiansemal, sehingga menimbulkan dua perspektif yang berbeda, kurangnya sosialisasi mengenai aturan pelaksanaan kebijakan sistem zonasi.

\section{Simpulan}

Pelaksanaan kebijakan Sistem Zonasi dalam Penerimaan Peserta Didik Baru di SMPN 1 Abiansemal untuk upaya pemerataan akses dan mutu pendidikan belum optimal. Hal ini dilihat dari dimensi efektivitas, kecukupan, ketepatan dan pemerataan kebijakan zonasi belum tercapai. Selain itu pemerataan akses dan pemerataan mutu yang belum dapat diwujudkan dalam pelaksanaan kebijakan sistem Zonasi di SMPN 1 Abiansemal, disebabkan karena pemetaan zona belum ditetapkan secara merata, serta penerimaan siswa tidak sesuai dengan zona yang ditetapkan dan terjadi penurunan mutu pendidikan.

Pelaksanaan kebijakan sistem Zonasi dalam Penerimaan Peserta Didik Baru (PPDB) di SMPN 1 Abiansemal, terdapat faktor pendukung dan faktor penghambat. Faktor pendukung dari pelaksanaan kebijakan sistem zonasi dalam Penerimaan Peserta Didik Baru (PPDB) di SMPN 1 Abiansemal, meliputi adanya koordinasi pihak dinas dan Kepala Sekolah sebelum dan setelah PPDB di laksanakan di SMPN 1 Abiansemal, serta telah memiliki SOP dan Juknis pelaksanaan kebijakan sistem zonasi dalam PPDB (Penerimaan Peserta Didik Baru) di SMPN 1 Abiansemal. Adapun faktor penghambat pelaksanaan kebijakan sistem Zonasi di SMPN 1 Abiansemal, meliputi kurangnya sarana dan prasarana, masih minimnya SDM (Sumber Daya Manusia). Dimana yang menjadi operator PPDB dari pihak guru sedangkan seharusnya sesuai aturan pihak TU yang memiliki wewenang untuk menjadi operator, tetapi disini ada 4 guru yang menjadi operator dan hanya satu guru yang memiliki SK sebagai operator sisanya membantu saat verifikasi dan penerimaan sehingga guru-guru ini tidak mendapatkan tunjangan kerja sebagai operator karena tidak sesuai dengan aturan. Pembatasan jumlah kuota yang ditentukan dari pihak sekolah tidak sebanding dengan jumlah calon peserta didik, penetapan zona berdasarkan alamat banjar dan jarak menjadi penghambat untuk menciptakan pemerataan akses pendidikan, tekanan dari pihak eksternal sekolah, kurang tegasnya pemimpin dalam menegakkan aturan, kurangnya komunikasi mengenai aturan yang mengatur pelaksanaan kebijakan sistem zonasi di Kabupaten Badung.

\section{Daftar Pustaka}

Abdul Hadis dan Nurhayati B. (2010). Manajemen Mutu Pendidikan. Bandung: Alfabeta. 
Adiwisastra, Irawati \& Purwanti. 2018Efektivitas Kebijakan Penerimaan Peserta Didik Baru Sistem Zonasi Bagi Siswa Rawan Menlanjutkan, Jurnal Ilmiah Ilmu Administrasi Negara, Universitas Galuh, Vol 5, No 4. Diakses dari https: //jurnal .unigal.ac.id/ index. php/ dinamika/ article/ view/1737/1409, pada 23 Juli 2020.

Anam, Hasbullah. 2019. Evaluasi Kebijakan Sistem Zonasi Dalam Penerimaan Peserta Didik Baru (PPDB) Di Tingkat Sekolah Menengah Pertama Negeri (SMPN) di Kabupaten Pamekasan. Jurnal Ilmiah Ilmu Sosial dan Ilmu Politik, Universitas Tribhuwana Tunggadewi, Vol 9 No.2. Diakses darihttps://jurnal. unitri. ac.id/index.php/reformasi/ article/view/1413/pdf, pada 23 Juli 2020.

Arikunto, Suharsimi;. (2006). Prosedur Penelitian. Jakarta: Rineka Cipta.

Bambang Sunggono. (1994). Hukum dan Kebijakan Publik.Jakarta:PT Karya Unipress.

Creswell, J. W. (2014). Research Design Pendekatan Kualitatif, Kuantitatif, dan Mixed. Yogyakarta: Pustaka Pelajar.

Desi Wulandari, 2018. Pengaruh Penerimaan Peserta Didik Baru Melalui Sistem Zonasi Terhadap Prestasi Belajar Siswa Kelas VII Di SMPN 1 Labuhan Ratu Lampung Timur Tahun Pelajaran 2017/2018. Diaksesdarihttp://digilib.unila.ac.id/30935/20/SKRIPSI\% 20TANPA \%20BAB\% 20PEMBAHASAN.pdf, pada 26 November 2019.

Desrijayanti, R. (2019). Pengaruh Penerapan Manajemen Berbasis Sekolah Terhadap Peningkatan Mutu Pendidikan Di Sekolah Menengah Pertama Negeri 2 Batang Peranap.

Desrijayanti, 2019. Pengaruh Penerapan Manajemen Berbasis Sekolah Terhadap Peningkatan Mutu Pendidikan di Sekolah Menengah Pertama Negeri 2 Batang Peranap. Diakses dari http:// repository.uin-suska.ac.id/20910/, pada 4 Februari 2020.

Dunn. (1999). Pengantar Analisis Kebijakan Publik. Yogyakarta: Gadjah Mada University Press.

Ghozali, Imam;. (2006). A plikasi Analisis Multivare Dengan Program SPSS. Semarang: Badan Penerbit Universitas Diponegoro.

Hoerudin, 2019. Implementation Of Admission Policy For New Studentswith Zonation System In Indonesia. International Journal Of Humanities, International Academy Of Scinence, Engineering and Technology, Vol.8 No.5. Diakses dari http://digilib.uinsgd.ac.id, pada 23 Juli 2020.

https://e-ppid.kemdikbud.go.id

https://www.bps.go.id/

https://balicitizen.com/bali-masuk-10-besar-wilayah-yang-banyak-adukan-masalah-PPDB/

https://www.balipost.com/

Jones. (1996). Pengantar Kebijakan Publik. Jakarta: PT Raja Grafindo Persada.

Kencana, Inu;. (2003). Sistem Administrasi Negara. Bandung: Bumi Aksara.

Marzuqi,2017. Mutu Pendidikan. Diakses dari http://etheses. iainkediri.ac.id /109/3/BAB\%20II.pdf, pada 22 Desember 2019.

Miles, Matthew B; Huberman, Michael;. (2007). Analisis Data Kualitatif Buku Sumber Tentang Metode-Metode Baru. Jakarta: Universitas Indonesia.

Nurlailiyah. 2019. Analisis Kebijakan Sistem Zonasi Terhadap Perilaku Siswa SMP di Yogyakarta.Jurnal Universitas Islam Negeri Kalijaga Yogyakarta, Vol.17 No.1. Diaksesdari https:// jurnal.iainkediri.ac.id /index. Php /realita /article /view /1381/735, pada 23 Juli 2020.

Noor, J. (2014). Metodologi Penelitian. Jakarta: Kencana.

Nugroho, R. (2014). Public Policy. Jakarta: PT Elex Media Komputindo.

Nugroho, Riant. (2009). Public Policy. Jakarta: PT Elex Media Komputindo. 
Pasolong, H. (2008). Teori A dministrasi Publik. Bandung: Alfabeta.

Pasolong, Harbani. (2012). Metode Penelitian A dministrasi Publik. Bandung: Alfabeta.

Permendikbud Nomor 44 Tahun 2019 Tentang Penerimaan Peserta Didik Baru

Peraturan Menteri Pendidilkan dan Kebudayaan Republik Indonesia Nomor 22 Tahun 2020 Tentang Rencana Strategis Kementerian Pendidikan dan Kebudayaan Tahun 2020-2024

Pada Taman Kanak-Kanak, Sekolah Dasar, Sekolah Menengah Pertama, Sekolah Menengah Atas, Sekolah Menengah Kejuruan, Atau Bentuk Lain yang Sederajat.

Rukiyati, Pradewi. 2019. Kebijakan Sistem Zonasi dalam Perspektif Pendidikan. Jurnal Manajemen dan Supervisi Pendidikan, Vol.4 No.1. Diakses dari http://journal2.um.ac.id/index.php/jmsp, pada 16 Juli 2020.

Subarsono, A. (2005). Analisis Kebijakan Publik. Yogyakarta: Pustaka Pelajar.

Sugesti, Tutik; Purba, Sukarman;. (2017). Strategi Peningkatan Mutu Pendidikan Di Madrasah Aliyah Persiapan Negeri 4 Medan. Jurnal Manajemen Pendidikan, 9, 56.

Sugiyono. (2009). Metode Penelitian A dministrasi. Bandung: Alfabeta.

Sugiyono. (2014). Metode Penelitian A dministrasi. Bandung: Alfabeta.

Usman, Husaini. (2009). Manajemen: Teori, Praktik, dan Riset Pendidikan. Jakarta: Bumi Aksara. wibawa, Samodra. (1994). Evaluasi Kebijakan Publik. Yogyakarta: PT Rajagrafindo Persada.

Winarno, B. (2008). Kebijakan Publik Teori, Proses, Dan Studi Kasus. Yogyakarta: CAPS.

Wirawan. (2011). Evaluasi Teori, Model, Standar, Aplikasi, Dan Profesi. Jakarta: PT Rajagrafindo Persada.

Made, Yudhiantara. (2008). Metode Penelitian Kualitatif. Denpasar: Graha Media Saraswati. 